\title{
Analisis Kekuatan Konstruksi Wing Tank Kapal Tanker Menggunakan Metode Elemen Hingga
}

\author{
Dedi Dwi Sanjaya, Septia Hardy Sujiatanti, dan Totok Yulianto \\ Departemen Teknik Perkapalan, Fakultas Teknologi Kelautan, Institut Teknologi Sepuluh Nopember \\ (ITS) \\ e-mail: septi@na.its.ac.id, totoky@na.its.ac.id
}

\begin{abstract}
Abstrak-Setiap kapal yang akan dibangun harus memenuhi standart (rules) yang telah ditetapkan oleh masing-masing biro klasifikasi. Salah satu prinsip dalam merancang suatu konstruksi adalah menciptakan jenis konstruksi yang sesuai dengan standar regulasi. Dalam pembangunan sebuah kapal, tidak akan terlepas dari pemakaian penegar. Dengan nilai modulus yang sama, jenis penegar yang dapat digunakan bisa berupa L-profile, I-profile, ataupun bulb plate. Penentuan jenis profil penegar pada pelat berdasarkan regulasi klasifikasi tidak ditentukan secara pasti, asalkan modulusnya memenuhi batas yang diijinkan, maka konstruksi tersebut disetujui oleh klasifikasi. Oleh karena itu penelitian ini dibuat untuk mengetahui profil mana yang paling efektif digunakan sebagai penegar pelat ditinjau dari besarnya tegangan yang terjadi dan berat konstruksinya. Variasi penegar yang digunakan pada penelitian ini adalah bulb plate, uequal leg angles, dan equal leg angles. Setiap variasi penegar ditentukan berdasarkan nilai modulus yang sama. Analisis dilakukan menggunakan metode elemen hingga dengan studi kasus konstruksi pelat berpenegar wing tank kapal tanker 17500 LTDW. Pemodelan dilakukan dengan software FEM. Hasil yang didapatkan berupa nilai tegangan von mises, deformasi, dan berat konstruksi pada setiap variasi. Dari hasil analisis, maka didapatkan besar tegangan maksimum pada bulb plate yaitu 49,5 MPa dengan berat konstruksi 39,323 ton, besar tegangan maksimum pada unequal leg angles yaitu 55 MPa dengan berat konstruksi 41,003 ton, dan besar tegangan equal leg angles yaitu 51,5 MPa dengan berat konstruksi 42,625 ton. Maka dapat ditarik kesimpulan bahwa bulb plate merupakan profil yang paling efektif dengan tegangan kecil dan berat konstruksi kecil. Hasil dari penelitian ini dapat diaplikasikan pada dunia industri sebagai acuan dalam memilih profil penegar yang paling efektif.
\end{abstract}

Kata Kunci-Analisis Tegangan, Metode Elemen Hingga, Pelat Berpenegar, Wing Tank.

\section{PENDAHULUAN}

$\mathrm{K}$ ONSTRUKSI kapal baja merupakan hal yang paling primary dalam menopang bentuk dalam pembangunan kapal. Salah satu prinsip dalam merancang suatu konstruksi adalah menciptakan jenis konstruksi yang sesuai dengan standar regulasi. Konstruksi bisa dikatakan sesuai standar regulasi apabila konstruksi mampu bertahan pada semua beban yang bekerja pada konstruksi tersebut sesuai dengan peraturan klasifikasi yang terkait. Selain dapat mampu bertahan pada semua beban yang bekerja, konstruksi juga akan dibangun seringan mungkin tanpa mengurangi batasan kekuatan yang telah ditentukan klasifikasi, sehingga akan lebih menguntungkan dalam segi finansial.
Pada umumnya, kapal-kapal besar dibangun dengan material baja, termasuk pada sistem konstruksinya. Pemakaian lembaran-lembaran pelat baja tidak akan lepas dari penggunakan penegar yang berfungsi sebagai penguatan pelat. Dengan nilai modulus yang sama, jenis penegar yang dapat dipakaipun bisa bermacam - macam, bisa berupa L-profile, Iprofile dan bulb plate sesuai dengan desainer kapal tersebut. Penentuan jenis profil penegar pada pelat berdasarkan peraturan klasifikasi tidak ditentukan secara pasti, asalkan perhitungan beban dan modulusnya memenuhi batas yang diijinkan, maka konstruksi tersebut disetujui oleh klasifikasi. Sehingga pemilihan jenis profilnya bisa dilakukan sesuai pilihan desainer tanpa mempertimbangkan kekuatan konstruksi yang diperkuat dengan profil tersebut.

Oleh karena itu, untuk mengetahui hasil analisis kekuatan konstruksi pelat berpenegar pada setiap variasi profil penegar, penulis melakukan penelitian dengan judul "Analisis Kekuatan Konstruksi Wing Tank Kapal Tanker Menggunakan Metode Elemen Hingga", sehingga akan diketahui kekuatan konstruksi untuk masing - masing profil penegar dengan nilai modulus yang sama. Konstruksi yang ditinjau pada penelitian ini adalah konstruksi wing tank pada kapal Tanker di bagian ruang muat midship. Hasil dari penentuan profil yang paling menguntungkan dilihat dari segi nilai kekuatan dan total berat konstruksinya.

\section{STUDI LITERATUR}

Pada penelitian ini menggunakan dasar teori perhitungan pembebanan berdasarkan peraturan Common Structural Rule (CSR) for Double Hull Oil Tanker 2012. Penelitian ini juga memerlukan perhitungan modulus penampang profil penegar untuk menentukan variasi profil yang akan digunakan dengan modulus yang sama.

\section{A. Perhitungan Pembebanan}

Pembebanan yang terjadi pada inner shell adalah beban statis dari tangki muat dan tangki ballast (wing tank), yang kemuadian diambil beban kritis yang terbesar. Kemudian juga perlu dibandingkan dengan perhitungan beban pengujian tangki yang sudah diatur dalam rules. Beban dipilih berdasarkan nilai perhitungan yang terbesar [1].

Berikut adalah beberapa persamaan yang digunakan dalam perhitungan beban.

$>$ Tekanan statis yang terjadi pada tangki 


$$
P_{\text {in-tk }}=\rho \cdot g \cdot z_{\mathrm{tk}} \quad \mathrm{kN} / \mathrm{m}^{2}
$$

Dimana, $\mathrm{Z}_{\mathrm{tk}}$ adalah jarak vertikal paling atas tangki ke pusat beban dalam satuan meter, $\rho$ adalah massa jenis fluida pada tangki; 0,91 untuk tangki muatan minyak (ton $\left./ \mathrm{m}^{3}\right) ; 1,025$ untuk tangki ballast air laut (ton $\left./ \mathrm{m}^{3}\right)$, g adalah percepatan gravitasi, $9,81 \mathrm{~m} / \mathrm{s}^{2}$

$>$ Tekanan akibat pengujian tangki, diambil nilai terbesar dari dua rumus berikut:

$$
\begin{gathered}
P_{\text {in-test }}=\rho_{\text {sw }} \cdot g \cdot z_{\text {test }} \mathrm{kN} / \mathrm{m}^{2} \\
P_{\text {in-test }}=\rho_{\text {sw }} \cdot g \cdot z_{\text {test }}+P_{\text {valve }} \mathrm{kN} / \mathrm{m}^{2}
\end{gathered}
$$

Dimana, $z_{\text {test }}$ adalah jarak vertikal ke pusat beban; dipilih jarak yang paling besar dari (dalam meter); (a) Tinggi overflow; (b) 2.4 diatas atap tangki, $\rho$ adalah massa jenis air laut $1,025 \mathrm{ton} / \mathrm{m}^{3}$, g adalah percepatan gravitasi $9,81 \mathrm{~m} / \mathrm{s}^{2}$, $\mathrm{P}_{\text {valve }}$ adalah pengaturan katup pelepas tekanan (desain kapal $14 \mathrm{kN} / \mathrm{m}^{2}$ ).

\section{B. Struktur}

Sistem konstruksi adalah gabungan dari berbagai konstruksi yang saling terhubung satu sama lain yang membentuk satu kesatuan untuk menahan gaya yang diterima sesuai dengan tujuan pembangunan sistem tersebut. Sistem konstruksi pada wing tank kapal tanker yang menjadi objek dalam penelitian ini meliputi sistem konstruksi memanjang dimana sebagian besar sistem konstruksi dibentuk oleh pelat dan profil penegar memanjang.

Merancang struktur adalah tindakan menempatkan unsurunsur pokok dan merumuskan hubungan-hubungan timbal baliknya dengan tujuan menanamkan karakter yang diinginkan pada entitas struktur sebagai resultannya. Gagasan bahwa unsur-unsur itu ditempatkan dan hubungan itu berkaitan erat dengan setiap unsur-unsur merupakan konsep dasar merancang struktur [2].

\section{Sekat Kedap Membujur}

Susunan konstruksi pada sekat rata sama dengan susunan konstruksi pada lambung kapal. Jika lambung menggunakan gading-gading tegak, pada sekat memanjang dipasang penegarpenegar tegak. Pada sistem konstruksi memanjang diperlukan pelintang sisi pada sekat yang dihubungkan dengan pelintang pada geladak dan pelintang sisi pada lambung kapal. Palang pengikat menghubungkan antara pelintang sisi pada lambung dan pelintang sisi pada sekat [3].

\section{Penegar}

Stiffener adalah bantalan pengaku atau pelat yang digunakan pada titik tumpuan suatu balok ketika balok tidak memiliki kemampuan pada badan profil untuk mendukung reaksi akhir atau beban terpusat. Batas untuk kondisi ini antara lain leleh lokal pada web (web local yielding), web crippling dan tekuk lokal web. Tekuk lokal web dapat terjadi bila balok diberi gaya tekan terpusat dan pergerakan lateral antara flange tekan dan flange tarik yang terbeban, tetap sejajar saat terjadi tekuk pada web [4].
Gambar 1. Ilustrasi stiffener pada pelat

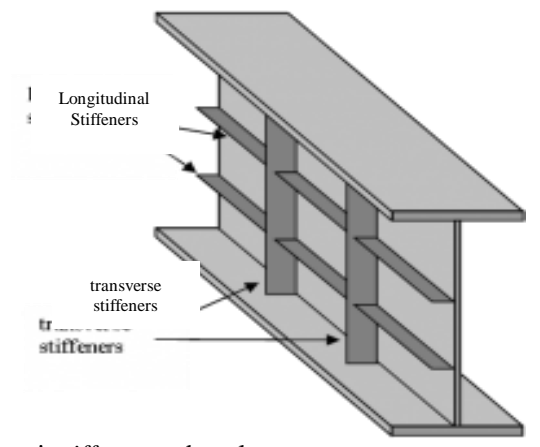

\section{E. Kekuatan Material}

Kekuatan material adalah kemampuan sebuah material untuk dapat menahan tekanan yang diberikan tanpa mengalami kegagalan atau failure. Bidang kekuatan bahan berkaitan dengan beban, deformasi dan gaya yang bekerja pada suatu material. Sebuah beban yang diterapkan kepada anggota mekanis akan mendorong kekuastan internal di dalam anggota yang disebut tegangan (stress). Tekanan yang bekerja pada material menyebabkan deformasi pada diri material tersebut. Deformasi dari bahan disebut regangan, sedangkan intensitas dari kekuatan-kekuatan internal yang disebut stress [5].

Konsep dasar dari tegangan dan regangan dapat diilustrasikan dengan meninjau sebuah batang prismatik yang dibebani gaya-gaya aksial (axial forces) $\mathrm{P}$ pada ujungujungnya. Sebuah batang prismatik adalah sebuah batang lurus yang memiliki penampang yang sama pada keseluruhan pajangnya [6].

\section{F. Tegangan Batas, Tegangan Ijin, Faktor Keamanan}

Faktor keamanan adalah faktor yang menunjukkan tingkat kemampuan suatu bahan teknik menerima beban dari luar, yaitu beban tekan maupun tarik. Gaya yang diperlukan agar terjadi tingkat optimal bahan di dalam menahan beban dari luar sampai akhirnya menjadi pecah disebut dengan beban ultimate atau ultimate load. Dengan membagi beban ultimate dengan luas penampang, maka akan didapatkan ultimate strength dari suatu bahan. Untuk desain bagian-bagian struktur tingkat tegangan disebut tegangan ijin (allowable stress) dibuat benar-benar lebih rendah daripada kekuatan ultimate yang diperoleh dari pengujian statis [5].

$$
\begin{gathered}
\text { Teganganijin }\left(\sigma_{i j i n}\right)=\frac{\text { tegangan lelah }\left(\sigma_{y}\right)}{\text { faktor keamanan }(n)} \\
\text { Faktor keamanan }(n)=\frac{\sigma_{\text {ultimate }}}{\sigma_{i j i n}}
\end{gathered}
$$

\section{G. Deformasi}

Deformasi dapat disebabkan baik oleh respon sekunder atau tersier dari hull girder. Respon sekunder berhubungan dengan tekukan global (global bending) dari panel-panel berpenegar. Respon tersier berhubungan dengan defleksi dan tegangan dari panel pelat yang tidak berpenegar yang terletak diantara dua pembujur dan dua gading besar.

Selama deformasi, bahan menyerap energi sebagai akibat adanya gaya yang bekerja. Sekecil apapun gaya yang bekerja, maka benda akan mengalami perubahan bentuk dan ukuran. 
Deformasi ada dua macam, yaitu deformasi elastis dan deformasi plastis. Deformasi elastis adalah deformasi yang terjadi akibat adanya beban yang jika beban ditiadakan, maka material akan kembali seperti ukuran dan bentuk semula, sedangkan deformasi plastis adalah deformasi yang bersifat permanen jika bebannya dilepas [7].

\section{H. Tumpuan}

sifat - sifat gaya reaksi yang timbul pada suatu benda yang mendapat beban tergantung bagaimana benda tersebut ditumpu atau bagaimana benda tersebut disambung dengan benda lain. Ada beberapa pengondisian tumpuan pada sebuah struktur. Pada umumnya tumpuan yang sering kita jumpai pada strukur adalah tumpuan jepit, roll dan tumpuan sendi.

Selain ketiga jenis tumpuan tersebut juga masih ada beberapa jenis seperti tumpuan sederhana dan tumpuan kabel. Semua jenis tumpuan tersebut merupakan suatu idealisasi dengan keadaan aktual yang berada pada struktur [7].

\section{Metode Elemen Hingga}

Metode elemen hingga adalah sebuah metode yang menggunakan pendekatan numerik untuk menganalisis sebuah struktur untuk mendapatkan solusi pendekatan dari suatu masalah. Pada dasarnya, langkah awal pada setiap simulasi menggunakan elemen hingga adalah membagi (to discritize) geometri dari struktur sesungguhnya menggunakan sekumpulan elemen-elemen yang berhingga. Sekumpulan titik nodal dan suatu elemen hingga disebut dengan mesh. Banyaknya elemen per satuan panjang, area, atau pada suatu mesh disebut dengan mesh density. Pada suatu analisis statik mekanika benda padat (solid), perpindahan (displacements) dari titik nodal adalah variabel dasar yang akan dikalkulasi oleh analis (dengan bantuan perangkat lunak). Tegangan, regangan, gaya dalam, serta gaya luar dapat ditentukan setelah perpindahan pada setiap titik nodal diketahui [5].

Suatu analisis menggunakan elemen hingga merupakan analisis pendekatan sehingga hasil yang didapatkan bukanlah suatu hasil analitis/tepat. Terdapat ketidaksesuaian (error) dari hasil yang didapat dengan hasil yang seharusnya. Namun terdapat suatu batasan yang dapat ditoleransi sehingga hasil dari analisis menggunakan elemen hingga dapat dinyatakan valid. Persamaan metode elemen hingga secara umum adalah sebagai berikut:

$$
\{f\}=[k] .\{d\}
$$

Dimana, $\{\mathrm{f}\}$ adalah matrik gaya, $[\mathrm{k}]$ adalah matrik kekakuan, $\{\mathrm{d}\}$ adalah matrik deformasi.

Analisis kekuatan dengan metode elemen hingga digunakan untuk mendapatkan nilai tegangan von mises. Suatu konstruksi dinyatakan memenuhi apabila besarnya nilai von mises stress $\left(\sigma_{\mathrm{vm}}\right)$ kurang dari yield stress material $\left(\sigma_{\mathrm{y}}\right)$.Persamaan von mises dituliskan sebagai berikut.

$$
\begin{gathered}
\sigma_{v m}=\sqrt{I_{1}{ }^{2}-3 I_{2}} \\
I_{1}=\sigma_{x}+\sigma_{y}+\sigma_{z} \\
I_{2}=\sigma_{x} \sigma_{y}+\sigma_{y} \sigma_{z}+\sigma_{z} \sigma_{x}-\tau_{x z}{ }^{2}-\tau_{y z}{ }^{2}-\tau_{x y}{ }^{2}
\end{gathered}
$$

Dimana, nilai $\sigma$ adalah tegangan normal, $\tau$ adalah tegangan geser [8].

\section{PEMODELAN}

\section{A. Pembuatan Geometri}

Penelitian ini menggunakan metode Bottom-Up, yaitu pemodelan dimulai dari pendefinisian tata letak titik (keypoint), penghubungan garis (line), plot bidang luasan (area), kemudian penggabungan menjadi volume. Ketebalan pada pelat sudah dimodelkan pada geometri sehingga tidak perlu pendefinisian tebal pada model konstruksi ini. Setiap bagiann konstruksi dihubungkan pada satu node yang sama sehingga terjadi kontinuitas atau kesatuan pada seluruh bagian konstruksi wing tank.

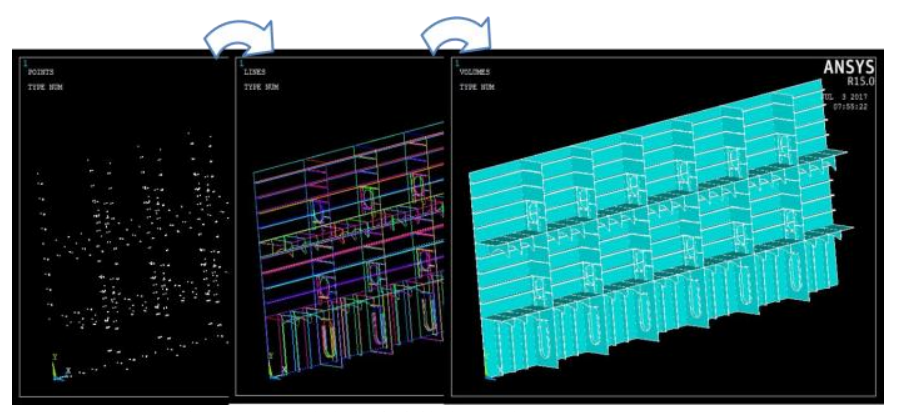

Gambar 2. Pembuatan model dari titik ke volume

\section{B. Variasi Profil yang Digunakan}

Pada penelitian ini digunakan variasi jenis profil penegar pada studi kasus wing tank kapal tanker dengan konstruksi yang disamakan dengan kondisi sebenarnya. Dalam menentukan dimensi variasi profil penegarnya, digunakan perhitungan tabulasi momen inersia dengan acuan nilai modulus yang disamakan pada setiap variasi. Berikut adalah hasil perhitungan dimensi variasi profil penegar yang digunakan.

Tabel 1.

Variasi Profil Penegar

\begin{tabular}{ccccccc}
\hline \hline & \multicolumn{2}{c}{ Variasi 1} & \multicolumn{2}{c}{ Variasi 2} & \multicolumn{2}{c}{ Variasi 2 } \\
& \multicolumn{2}{c}{ Bulb Plate } & \multicolumn{2}{c}{ Unequal Leg Angles } & \multicolumn{2}{c}{ Equal Leg Angles } \\
\cline { 2 - 7 } & Dimensi & $\mathrm{W}$ & Dimensi & $\mathrm{W}$ & Dimensi & $\mathrm{W}$ \\
& $(\mathrm{mm})$ & $\left(\mathrm{cm}^{3}\right)$ & $(\mathrm{mm})$ & $\left(\mathrm{cm}^{3}\right)$ & $(\mathrm{mm})$ & $\left(\mathrm{cm}^{3}\right)$ \\
Bawah & BP 260x11 & 105 & L 221x130x13 & 105,1 & L 199x199x15 & 105,3 \\
Tengsh & BP 240x11 & 137 & L 210x120x13 & 137,3 & L 209x209x12 & 137,6 \\
Atas & BP 220x10 & 153 & L 189x125x12 & 153,3 & L 177x177x13 & 153,3 \\
\hline \hline
\end{tabular}

\section{Meshing}

Pada model penelitian ini digunakan pemodelan solid 3D, sehingga digunakan meshing volume. Tipe elemen yang digunakan adalah solid 186 dengan 20 node, Karena pada elemen ini mendukung plastisitas, hyperelasticity, creep, stress stiffening, defleksi besar, dan kemampuan regangan yang besar. Elemen ini juga memiliki ketelitian yang lebih tinggi dibandingkan elemen solid lain dengan node yang lebih sedikit. Untuk penentuan ukuran meshing diambil dari hasil konvergensi.

\section{Konvergensi}

Uji konvergensi adalah salah satu cara dalam menentukan ukuran elemen yang tepat dalam pembuatan model elemen hingga sehingga model dapat menghasilkan nilai yang valid. Hasil konvergensi perlu dilakukan pengecekan terhadap aspek rasio elemen sesuai regulasi CSR (2012) tentang Cargo Tank Structural Analysis dengan persamaan: 


$$
\text { Aspek rasio }=\frac{\max \left(l_{i}\right)}{\min \left(l_{i}\right)} \leq 3
$$

Tabel 2.

Pemeriksaan Aspek Rasio

\begin{tabular}{cccccc}
\hline \hline Variasi & Bagian & $\begin{array}{c}\text { Tebal } \\
\text { Minimum } \\
(\mathrm{mm})\end{array}$ & $\begin{array}{c}\text { Ukuran } \\
\text { Meshing } \\
(\mathrm{mm})\end{array}$ & $\begin{array}{c}\text { Aspek } \\
\text { Rasio }\end{array}$ & Keterangan \\
\hline Bulb Plate & Pelat & 14 & 40 & 2,857 & memenuhi \\
Equal Leg & Penegar & 10 & 30 & 3,0 & memenuhi \\
Angles & Penegar & 14 & 30 & 2,143 & memenuhi \\
Unequal Leg & Pelat & 12 & 15 & 1,25 & memenuhi \\
Angles & Penegar & 12 & 30 & 2,143 & memenuhi \\
\hline \hline
\end{tabular}

\section{E. Kondisi Batas (Constraint)}

Pada penelitian ini, kondisi batas diaplikasikan pada sisi depan dan sisi belakang wing tank akibat pertemuan dengan sekat melintang, sisi atas akibat pertemuan dengan deck, sisi bawah akibat pertemuan dengan bottom, dan sisi luar akibat pertemuan web dengan side shell. Elemen yang digunakan memiliki tiga derajat kebebasan, sehingga kondisi batas berupa translasi ke arah sumbu x, y, z seperti pada Tabel 3 .

Tabel 3.

Kondisi Batas Pada Model

\begin{tabular}{ccc}
\multicolumn{3}{c}{ Kondisi Batas Pada Model } \\
\hline \hline UX & Translasi \\
Fix & UY & UZ \\
& Fix & Fix \\
\hline \hline
\end{tabular}

\section{F. Pembebanan}

Penentuan besarnya beban muatan yang diaplikasikan pada model wing tank dihitung berdasarkan peraturan Common Structure Rules for Double Hull Oil Tanker Section 7 Tahun 2012. Terdapat dua rumus perhitungan beban, yaitu beban akibat muatan (cargo tank dan ballast tank) dan beban dari pengujian (testing pressure). Dari semua hasil perhitungan, dipilih nilai beban terbesar yang diaplikasikan pada model.

Tabel 4.

Beban Pada Model

\begin{tabular}{ccccc}
\multicolumn{5}{c}{ Beban Pada Model } \\
\hline \hline Plate & I & II & III & Unit \\
\hline$Z_{\text {tk }}$ & 9,9 & 6,8 & 3,7 & $\mathrm{~m}$ \\
Pin-tk $_{\text {in-k }}$ & 99,547 & 68,376 & 37,204 & $\mathrm{kN} / \mathrm{m}^{2}$ \\
\hline \hline
\end{tabular}

Beban tersebut diaplikasikan pada area model dalam bentuk persamaan segitiga dengan fungsi y tinggi sekat.

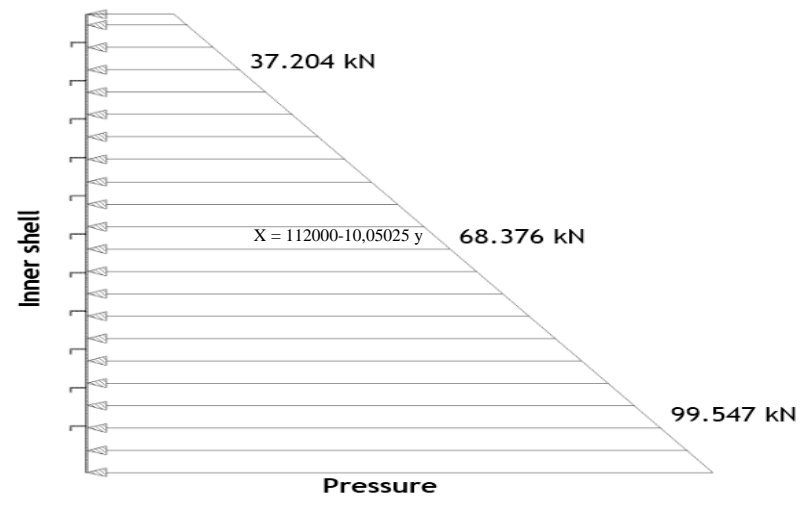

Gambar 3. Pendefinisian beban segitiga pada model

\section{ANALISIS DAN PEMBAHASAN}

\section{A. Tegangan Maksimum}

Hasil dari analisis tegangan konstruksi wing tank ini menghasilkan beberapa jenis tegangan. Tegangan yang dipilih pada analisis ini adalah von mises stress. Tegangan von mises digunakan untuk memprediksi tingkat keluluhan material terhadap kondisi pembebanan tertentu.

Dari hasil tegangan von mises dilakukan pemeriksaan terhadap batas tegangan ijin sesuai regulasi CSR 2012 Section 9 Chapter 2 tentang Strength Assessment (FEM) dengan persamaan:

$$
\lambda_{y}=\frac{\sigma_{v m}}{\sigma_{y d}} \leq 0.72
$$

Dimana:

$\sigma_{\mathrm{vm}}=$ tegangan maksimum von mises

$\sigma_{\mathrm{yd}}=$ tegangan yield material $(235 \mathrm{Mpa})$

Tabel 5 .

Rekapitulasi Analisis Tegangan

\begin{tabular}{ccccccc}
\hline \hline No & Model & $\begin{array}{c}\text { Tegangan } \\
\text { Maksimum }\left(\sigma_{\text {max }}\right) \\
(\mathrm{MPa})\end{array}$ & $\begin{array}{c}\text { Tegangan } \\
\text { Batas } \\
\left(\sigma_{\text {yield }}\right) \\
(\mathrm{MPa})\end{array}$ & $\lambda_{\mathrm{y}}$ & $\lambda_{\mathrm{ijin}}$ & $\begin{array}{c}\text { Syarat } \\
\lambda_{\mathrm{y}} \leq \lambda_{\mathrm{jijin}}\end{array}$ \\
\hline 1 & Bulb Plate & 49,5 & 235 & 0,21 & 0,72 & memenuhi \\
2 & $\begin{array}{c}\text { Unequal Leg } \\
\text { Angles } \\
\text { Equal Leg } \\
\text { Angles }\end{array}$ & 55 & 235 & 0,23 & 0,72 & memenuhi \\
\hline \hline
\end{tabular}

Dari Tabel 5 dapat dinyatakan bahwa ketiga model sudah memenuhi standar maksimum tegangan ijin. Maka dari hasil tersebut dibuat grafik tegangan sebagai berikut.

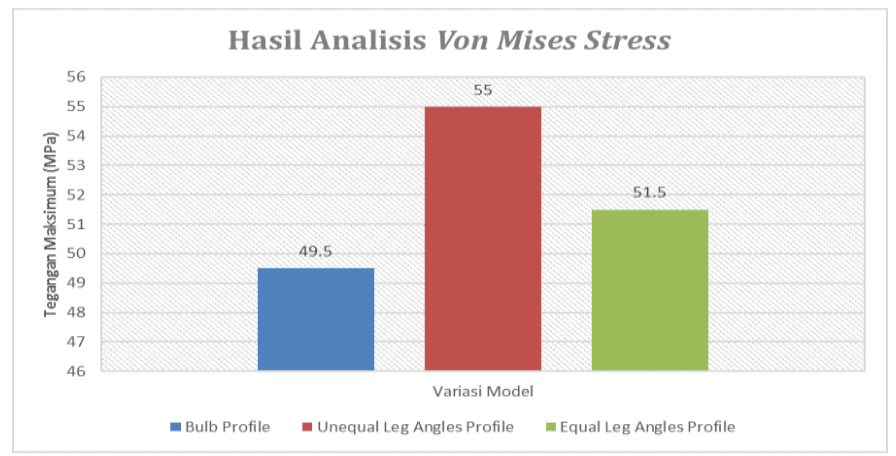

Gambar 4. Grafik tegangan maksimum

Pada model 1 penegar bulb plate mengalami tegangan maksimum sebesar 49,5 MPa dengan titik maksimum pada sambungan antara penegar dengan web. Pada model 2 penegar unequal leg angles profile mengalami tegangan maksimum sebesar 55 MPa dengan titik maksimum pada sambungan antara penegar dengan web. Pada model 3 penegar equal leg angles profile mengalami tegangan maksimum sebesar 51,5 MPa dengan titik maksimum pada sambungan antara penegar dengan web.

\section{B. Deformasi Maksimum}

Dilakukan analisis deformasi maksimum untuk melihat respon model terhadap pembebanan dan constraint yang diberikan. Hasil deformasi maksimum adalah sebagai berikut. 
Tabel 6.

Rekapitulasi Deformasi Maksimum

\begin{tabular}{ccc}
\hline \hline No & Model & $\begin{array}{c}\text { Deformasi Maksimum } \\
(\mathrm{mm})\end{array}$ \\
\hline 1 & Bulb Plate & 3,74 \\
2 & Unequal Leg Angles & 4,31 \\
3 & Equal Leg Angles & 3,86 \\
\hline \hline
\end{tabular}

Dari Tabel 6 menunjukkan bahwa nilai deformasi berbanding lurus dengan besarnya tegangan. Maka dari hasil tersebut dibuat grafik tegangan sebagai berikut.

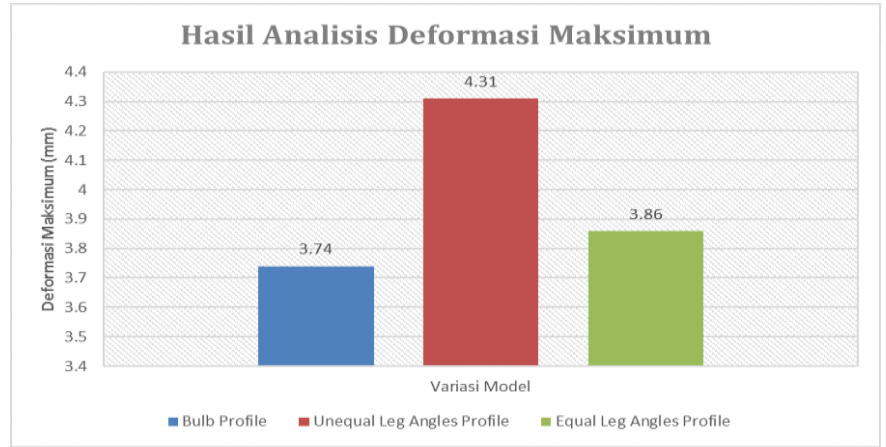

Gambar 5. Grafik deformasi maksimum

Pada model 1 bulb plate mengalami deformasi maksimum sebesar $3,74 \mathrm{~mm}$, model 2 unequal leg angles mengalami deformasi maksimum sebesar $4,31 \mathrm{~mm}$, sedangkan pada model 3 equal leg angles mengalami deformasi maksimum sebesar $3,86 \mathrm{~mm}$.

\section{Berat Konstruksi}

Besarnya berat konstruksi juga dipertimbangkan dalam penelitian ini. Hal ini bertujuan untuk menentukan model yang paling ringan dengan tegangan yang paling kecil. Berikut adalah hasil dari analisis berat konstruksi.

Tabel 7.

Rekapitulasi Berat Konsruksi

\begin{tabular}{ccc}
\hline \hline No & Model & $\begin{array}{c}\text { Berat Konstruksi } \\
\text { (ton) }\end{array}$ \\
\hline 1 & Bulb Plate & 39,323 \\
2 & Unequal Leg Angles & 41,001 \\
3 & Equal Leg Angles & 42,625 \\
\hline \hline
\end{tabular}

Dari Tabel 7 menunjukkan berat konstruksi terbesar pada model 3 sedangkan berat konstruksi terkecil pada model 1 .

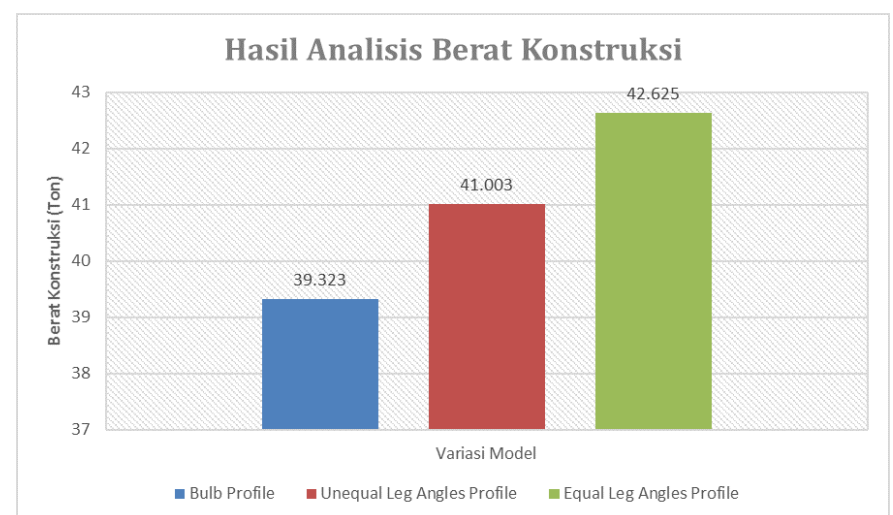

Gambar 6. Grafik berat konstruksi

Pada model 1 bulb plate berat konstruksi sebesar 39,323 ton, model 2 unequal leg angles berat konstruksi sebesar
41,003 ton, sedangkan pada model 3 equal leg angles berat konstruksi sebesar 42,625 ton.

\section{KESIMPULAN}

- Dengan modulus profil penegar yang sama, didapatkan nilai tegangan terbesar terjadi pada variasi tipe profil unequal leg angles dengan nilai $55 \mathrm{MPa}$, sedangkan tegangan terkecil terjadi pada variasi tipe profil bulb dengan nillai 49,5 MPa.

- Nilai deformasi berbanding lurus dengan nilai tegangan, nilai deformasi terbesar terjadi pada variasi tipe profil unequal leg angles dengan nilai $4,31 \mathrm{~mm}$, sedangkan deformasi terkecil terjadi pada variasi tipe profil bulb dengan nilai $3,74 \mathrm{~mm}$.

- Berat konstruksi terbesar terjadi pada variasi tipe profil equal leg angles dengan nilai 42,625 ton, sedangkan berat konstruksi terkecil terjadi pada variasi tipe profil bulb dengan nilai 39,323 ton.

- Tipe profil penegar yang paling efektif digunakan pada konstruksi dengan mempertimbangkan nilai tegangan terkecil dan berat konstruksi yang terkecil adalah penegar dengan tipe profil bulb.

\section{DAFTAR PUSTAKA}

[1] IACS, Common Structural Rules for Double Hull Oil Tankers. United Kingdom: IACS, 2012.

[2] D. L. Schodek, Struktur Edisi 3. Bandung: PT Refika Aditama, 1998.

[3] D. I. Kusna, Teknik Konstruksi Kapal Baja. Direktorat Pembinaan Sekolah Menegah Atas Departemen Pendidikan Nasional, 2008.

[4] V. Aghayere, Abi \& Jason, Structural Steel Design. United States of America, 2009.

[5] E. P. Popov, "Mechanics of Material 2nd edition," Prentice-Hall, 1978. .

[6] J. . \& S. P. T. Gere, Mekanika Bahan Edisi Kedua Versi SI. Jakarta: Erlangga, 1996.

[7] R. . Hibeller, Mechanics of Material Third Edition. 1997.

[8] K. N. Hoque, "Analysis of Structural Discontinuities in Ship Hull Using Finite Element Method," 2013. 